EDUCATION

Research, Innovation and Solutions on-line ${ }^{(0)}$
Electronic Journal of Research

in Educational Psychology

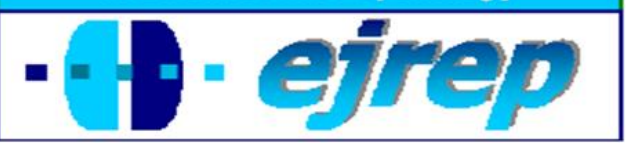

Editorial EOS

\title{
The role of mathematical homework and prior knowledge on the relationship between students' mathematical performance, cognitive style and working memory capacity
}

\section{Shima Mousavi, Farzad Radmehr, Hasan Alamolhodaei}

School of Mathematical Sciences, Ferdowsi University of Mashhad, Mashhad

Iran

Correspondence: Farzad Radmehr.School of Mathematical Sciences.Ferdowsi University of Mashhad. Mashhad.Iran. E-mail: f.radmehr65@gmail.com 


\begin{abstract}
Introduction. The main objective of this study is (a) to investigate whether cognitive styles and working memory capacity could predict mathematical performance and which variable is relatively most important in predicting mathematical performance and b) to explore whether cognitive styles and working memory capacity could predict mathematical performance when the impacts of students' prior math knowledge and the amount of math homework completed are controlled.
\end{abstract}

Method. The sample of 183 K9 school girls (15-16 years old) were tested on (1) the Witkin's cognitive style (Group Embedded Figure Test) (2) Digit Span Backwards Test (3) Homework questionnaire (4) Mathematics exam. Data of this research was analyzed by standard multiple regressions from SPSS (Statistical Package for the Social Sciences) software.

Results. Results obtained of standard regression indicated that both predictors were correlated with mathematical performance and consistently predicted mathematical performance. Also, standardized coefficients indicated that cognitive style $(\beta=.58)$ was stronger predictor of mathematical performance than working memory capacity $(\beta=.43)$. After controlling for students' prior math knowledge and the amount of math homework completed, finding of standard multiple regressions showed that cognitive style and working memory were still significant predictors of mathematical performance but the effects of these variables on mathematical performance decreased to .21 and .10 , respectively.

Discussion and Conclusion. According to results obtained, doing math homework and having high prior math knowledge may diminish the negative effects of being field dependent and having low working memory capacity on students' mathematical performance.

Keywords: Cognitive style. Working memory capacity. Prior math knowledge. Amount of math homework completed. Mathematical performance.

Received: 07/16/12 Initial acceptance: 07/25/12 Final acceptance: 11/01/12 


\section{El papel de los deberes y conocimientos previos matemáticos en la relación entre el rendimiento matemático, estilo cognitivo y capacidad de memoria de trabajo de los alumnos \\ Resumen}

Introducción. El objetivo principal de este estudio fue: a) investigar si los estilos cognitivos y la capacidad de memoria de trabajo puede predecir el rendimiento matemático y qué variables son más importante para predecir el rendimiento matemático, y b) para explorar si los estilos cognitivos y la capacidad de memoria de trabajo puede predecir el rendimiento matemático cuando se controlan el impacto del conocimiento previo de los estudiantes de matemáticas y la cantidad de tarea de matemáticas terminada.

Método. La muestra de 183 niñas de la escuela K9 (15-16 años) fueron probados en (1) el estilo cognitivo de Witkin (Grupo de pruebas Figura Embedded) (2) Digit Span Backwards prueba (3) Cuestionario Homework (4) examen de Matemáticas. Los datos de esta investigación se analizaron mediante regresión múltiple estándar de SPSS.

Resultados. Los resultados obtenidos de la regresión estándar indicaron que ambos predictores fueron correlacionados con el rendimiento matemático y consistentemente predijeron el rendimiento matemático. Además, los coeficientes estandarizados indicaron que el estilo cognitivo $(\beta=.58)$ fue más fuerte predictor de rendimiento matemático que la capacidad de memoria de trabajo $(\beta=.43)$. Después de controlar los conocimientos de estudiantes de matemáticas 'anterior y la cantidad de tarea de matemáticas terminado, las pruebas de regresión múltiple mostraron que el estilo cognitivo y la memoria de trabajo seguían siendo significativos predictores del desempeño matemático, pero los efectos de estas variables sobre el rendimiento matemático disminuido a $.21 \mathrm{y} .10$, respectivamente.

Discusión y conclusión. De acuerdo con los resultados obtenidos, hacer la tarea de matemáticas y los conocimientos de matemáticas previos, puede disminuir los efectos negativos de ser dependiente de campo y la baja capacidad de memoria de trabajo, en el rendimiento matemático de los estudiantes.

Palabras clave: estilo cognitivo; capacidad de memoria de trabajo; conocimiento matemático previo; cantidad de tarea de matemáticas terminada; rendimiento matemático. 


\section{Introduction}

The review of the literature discovers a consensus that, generally, cognitive style (FD/I) and working memory capacity predict mathematical performance. The majority of previous researches are correlational. That is, the effects of psychological variable (working memory and cognitive style) on mathematical performance were explored directly. It seems that the association between these factors and mathematical performance may be moderated by exogenous factors such as homework completion and prior math knowledge. It will thus be of interest to investigate the relationship between working memory and cognitive style with mathematical performance while controlling for students' prior math knowledge and the amount of math homework completed by them.

\section{Field Dependence/Independence cognitive style}

Cognitive style reflects an individual's preferred way of actively processing and transforming incoming information, categorizing new knowledge, and integrating it within the memory structure. It includes field dependence or independence, scanning, categorizing, conceptualization, simplicity or complexity, reflectivity or impulsivity, risk taking or cautiousness, and visual or kinesthetic preferences. Among the dimensions of cognitive style that have been identified to date, field dependence/independence (FD/I) has received most attention, particularly with regard to its educational implications (Quiroga \& González, 1988).

FD/I or disembedding ability refers to the degree of field dependence/ field independence, and represents the ability of a subject to dissembed information in a variety of complex and potentially misleading instructional context (Pascual-Leone, 1989; Witkin, Dyk, Paterson, Goodenough \& Karp, 1974). FD/I describes learners along a continuum such that individuals at one end are considered to be field dependent (FD), and individuals at the other end fieldindependent (FI). Individuals who fall in the middle of the continuum are characterized as field-mixed (FM) (Liu \& Reed, 1994). Some subjects are dominated by any strong frame of reference so that, they have difficulty perceiving elements that cut across the pattern. These subjects are characterized as field-dependent, because they insufficiently separate an item from its context and accept the dominating field or context. On the other hand, subjects who can easily separate an item from its context are characterized as field-independent (Witkin \& Goodenough, 1981). Field-independent subjects possess more analytical abilities and tend to 
'break' information, paying attention to the partial, while field-dependent subjects focus their attention preferably upon the global aspects of the given information (Grigorenko \& Sternberg, 1995; Tinajero \& Páramo, 1998). Therefore, FD/I cognitive style appears important in learning science: problem-solving and conceptual understanding (Bahar \& Hansell, 2000; Kang, Scharmann, Noh \& Koh, 2005; Tsaparlis, 2005).

Several instruments have been developed to assess the FD/I construct, including the widely used Embedded Figures Test (EFT), the Rod and Frame Test (RFT) and the Group Embedded Figures Test (GEFT) (Witkin et al. 1971). The GEFT is a traditional visuo-spatial test that involves figure ground segregation, which requires observers to find simple figures hidden in complex visual configuration.

Cognitive style has been reported to be one of the significant factors that may impact students' achievement on various school subjects (see, Murphy, Casey, Day, \& Young, 1997; Cakan, 2000; Altun \& Cakan 2006). Tinajero and Páramo (1998) investigated the relationship between cognitive styles and student achievement in several subject domains (English, mathematics, natural science, social science, Spanish, and Galician). With the sample of 408 middle school students, the researchers asserted that cognitive style was a significant source of variation in overall performance of students. That is, field independent subjects outperformed their field dependent counterparts. Nasser and Carifio (1993) attributed the superiority of field-independent subjects to their ability to break the problem into its parts, their tendency to pay attention to details and their restructuring abilities. The relationship between FD/I and mathematics has been the subject of particular interest, since mathematics is seen as an activity requiring a high level of disembedding or restructuring ability (Witkin, Moore, Goodenough, et al., 1977).

The general finding is that field independent students display superiority in mathematics achievement compared to field dependent students. Witkin and Goodenough (1981) discussed cognitive restructuring as an aspect of field dependence independence. Field independent individuals have easier time restructuring information from their environment in a problem solving situation. Therefore, it would be expected that field independent students would have an advantage over field dependent students in solving mathematical word problems. Solutions to such problems often require cognitive restructuring. Other researchers have also demonstrated the importance of field dependency in science education and mathematical 
problem solving, in particular word problems (Alamolhodaei, 2002, 2009; Ekbia \& Alamolhodaei, 2000; Johnstone \& AI-Naeme, 1991; Witkin \& Goodenough, 1981). In a more recent study, with the sample of 161 school girls (13-14 years old), Alamolhodaei (2009) also found that field independent students achieved higher results in both an ordinary mathematical exam and a word problem solving exam. Therefore, recent studies showed that cognitive styles (FD/I), which are based upon individual differences, had a significant and positive association with students' mathematical performance.

\section{Working Memory}

The concept of working memory that has been widely used in cognitive science refers to the human limited capacity system, which provides both information storage and processing functions (Atkinson \& Shiffrin, 1968), and is necessary for complex cognitive tasks, such as learning, reasoning, language comprehension, and problem solving. Baddeley and Hitch (1974) advocated that temporary memory processes, despite of involving dedicated memory systems, should be viewed within the context of more general cognitive mechanisms.

According to Baddeley' s (Baddeley \& Hitch, 1974; Baddeley \& Logie, 1999) multicomponent model, the three primary components of working memory are (a) the central executive, which is considered to be primarily responsible for the coordinating activity within the cognitive system and managing tasks in working memory, (b) the phonological loop, which is responsible for the temporary storage of verbal information (verbal working memory); items are held in a phonological store of limited duration, and the items are maintained within the store via the process of articulation, and (c) the visual-spatial sketchpad, which is responsible for the storage of visual-spatial information over brief periods(visual working memory), and it also plays a key role in the generation and manipulation of mental images.

Both the phonological loop and the visual-spatial sketchpad are in direct contact with the central executive. Central executive devotes some of its resources to increasing the amount of information that can be held in the two other components. Also, it is believed to support a variety of activities including controlling the flow of information through working memory, the retrieval of knowledge from long-term memory, the control of action and the scheduling of multiple concurrent cognitive activities (e.g ., Baddeley , 1996 ;Baddeley \& Hitch, 1974; Baddeley, Emslie, Kolodny, \& Duncan, 1998 ). In a recent reformulation of the 
model, Baddeley (2000) proposed a fourth component, the episodic buffer, which is a limited capacity system that integrates and provides temporary storage of information from the two subsystems and long-term memory. The working memory capacity of the students was assessed by means of the digit backward span (DBS) test, which is part of the Wechsler Adult Intelligence Scale (Wechsler, 1955).

Several researches indicated that individuals with higher levels of working memory capacity (WMC) perform better on learning tasks because they have more cognitive resources (Daneman \& Carpenter, 1980; Mayer, 2001; Mousavi, Low, \& Sweller, 1995). Working memory is implicated in academic performances, including reading comprehension and mathematics in both children and adults (Swanson, 1994). Many recent studies support the notion that working memory is related to arithmetic performance ( Fürst \& Hitch, 2000; Heathcote, 1994; Kyoung- Min \& So-Young , 2002; Logie, Gilhooly, \& Wynn, 1994; Alamolhodaei, 2009), mathematics problem solving (Cary \& Carlson, 2001; DeStefano \& LeFevre, 2004; Klein \& Bisanz, 2000; Seitz \& Schumann-Hengsteler, 2000; Swanson, 2004; Swanson \& Beebe-Frankenberger, 2004; Alamolhodaei, 2009), and even mathematics anxiety (Ashcraft \& Kirk, 2001).For example, studies reported by Adams and Hitch (1998) suggested that mental arithmetic performance relies on the resources of working memory. It seems that a major source of mathematical misunderstanding and errors should be sought in memory transformation and subjective organization (Alamolhodaei, 2009). In addition, Ekbia and Alamolhodaei (2000) reported that schoolboys with higher WM capacity were more successful than those with lower WM in the mathematical problem solving, particularly word problems. In another study, engineering students with high WM capacity achieved significantly better results than those with lower WM in the university mathematics exam (Alamolhodaei \& Ghazvini, 2003). Working memory is also important for mathematical problem solving on arithmetic word problems. Passolunghi and Siegel (2001) concluded that Grade 4 children who are poor at problem solving have significant difficulty with central executive tests of working memory and with digit span, which is often used as a measure of the phonological loop (e.g ., Gathercole et al., 2004 ).

Also, studies reported by Mabbot and Bisanz, (2008) suggested that digit span backward, that is most often described as a measure of both the phonological loop and the central executive (Rosen \& Engle, 1997), specifically distinguishes children with severe math difficulties from both children with less severe math difficulties, and children with typical 
achievement in mathematics. There is also some evidence that mathematically disabled students scored significantly lower on WM Span Tests. Thus, reduced working memory capacity is implicated in mathematics (Geary et al. 1991).

\section{Homework and prior math knowledge as control variables}

Homework has been defined simply as "tasks assigned to students by school teachers that are meant to be carried out during non-school hours" (Cooper, 1989). Teachers assign homework for many different reasons, although researchers have noted that most assignments usually serve multiple purposes. Homework provides an opportunity for students to extend and reinforce material that has already been presented in class (Cooper, 2007; Paulu, 1998) and for teachers to extend the time for learning beyond the hours of formal schooling. It may also be to prepare students in advance for work to be done in class the next day or later on, so that they obtain maximum benefit when the new material is covered in class (Mulhenbruck, Cooper, Nye \&Lindsay, 1999) or involve them in the transfer of previously learned skills to new situations (Lee \& Pruitt, 1979) or other areas of interest (Cooper et al., 2006; Shellard \& Turner, 2004).

Using meta-analytic strategies, Cooper (1989) analyzed 17 experimental and quasiexperimental studies conducted between 1962 and 1987. He concluded that academic achievement in classes where homework was assigned was higher than that in no-homework classes, and found an overall effect of $d=0.21$ favoring homework over no homework. The effect of homework assignment was stronger in higher grades (Grades 4-6: $d=0.15$; Grades 79: $\mathrm{d}=0.31$; Grades $10-12: \mathrm{d}=0.64$ ) and weaker in mathematics (overall $\mathrm{d}=0.16$ ). In addition, Hallam (2004) in her review of studies done on homework suggested that homework should be clearly related to ongoing classroom work, be varied, be manageable, be challenging but not too difficult, allow for individual initiative and creativity, promote self confidence and understanding and there should be recognition or reward for work done and guidance and support to complete the work. In Iran, in most mathematics lessons, teachers assign their students homework on a regular basis, i.e., after every lesson or after every two or more lessons. Also, according to previous researches (e.g., Aminzadeh \& Sarmad, 2009) due to the changes in the content of the math textbooks and also the more abstraction of the context in comparison with elementary mathematics, parents are not capable of helping their children. So, homework is usually meant to be done alone. Homework is most frequently done at home, but 
it may be done in school during study periods or after school hours in the library, or anywhere the student so wishes to do.

According to Ausubel's theory of meaningful (1963), new knowledge, if it is to be meaningful, would need to be incorporated, or subsumed, into existing knowledge structures (Ausubel, 1963, 1968). Meaning occurs when new knowledge is tied to relevant concepts and propositions in the learner's cognitive structure. It is from this relationship, or linking, with pre-existing concepts that a new concept is understood. If more meaningful materials are anchored to the existing cognitive structure, they are better learned and better retained. The most important fact for meaningful learning is what learners already know. As Ausubel advises (Ausubel, Navak, \& Hanesian, 1978), "If I had to reduce all of educational psychology to just one principle, I would say this: The most important single factor influencing learning is what the learner already knows. Ascertain this and teach him accordingly”.

Since prior knowledge is regarded as the critical factor influencing learning and academic achievement and also, several researchers showed that prior math knowledge is the most important predictive variable in math performance in comparison to the other variables under study (Bandura, 1997) then we consider this factor and variable of the amount of math homework completed as covariates in models to explore the main effects of cognitive style and working memory capacity on mathematical performance.

\section{Research framework}

Our research question is: Which psychological variables predict mathematical performance among adolescents? The review of the literature reveals a consensus that, generally, cognitive style (FD/I) and working memory capacity predict mathematical performance. For example, it was found that FI students tend to get higher results than FD students in calculus problem solving at university level. Moreover, school students with FI cognitive style achieved much better results than FD ones in mathematical problem solving, in particular word problems (Alamolhodaei, 2002). Therefore, recent studies showed a positive relationship between cognitive styles (FD/FI) and students' mathematical performance (Witkin and Goodenough 1981; Talbi 1990; Johnstone and Al-Naeme 1991, 1995; Alamolhodaei 1996; Ekbia and Alamolhodaei 2000; Alamolhodaei 2002; Alamolhodaei 2009). 
Also, past researches has investigated the underlying cognitive processes that contribute to individual differences in math performance, the most investigated of which appears to be working memory. Several studies have shown that the processes involved in working memory, namely, temporary retrieval, processing, and storage, explain much of the variance in math performance (e.g., Adams \& Hitch, 1998; Ashcraft, 1995; Brainerd, 1983; Hitch, 1978). Individuals who are more efficient and adept in carrying out these processes are likely to perform better on tests of math performance. So, our study will determine the strongest predictors of mathematical performance in a general population sample of $183 \mathrm{k} 9$ high school girl students.

It is hypothesized that prior knowledge will directly predict academic performance because historically students' performance on standardized tests has been considered an optimal predictor of their subsequent success in school. For example, Pajares's findings (1996) show that pervious attainments in math are strong predictors of subsequent mathematical performance. Bandura (1997) attributes a very important role to prior knowledge and its effect on students' subsequent attainment. He also emphasizes the inclusion of prior knowledge in causal analyses. Since, in recent studies the effect of students' prior knowledge was not considered in relationship between given psychological variables and mathematical performance then the researchers of this study used this factor as covariate in models.

Homework likely has a significant impact on students' educational trajectories. Most educators believe that homework can be an important supplement to in-school academic activities (Henderson, 1996). Homework provides an opportunity for students to extend and consolidate what they have learnt in school. Since, reinstating and consolidating the previous learned math skills and conceptual may decrease overloading on working memory capacity. Therefore, it seems to the researchers of this study that homework completion may moderate the effects of working memory capacity and cognitive style on mathematical performance. So, in this study researchers investigated the possible relationship between these factors while controlling for math prior knowledge and the amount of math homework completed.

Therefore, our hypotheses are as follows:

Hypothesis 1. Given the strong theoretical support in the literature, cognitive style and working memory capacity are expected to be significant positive predictors of mathematical performance. 
Hypothesis 2. Given the strong theoretical support in the literature, cognitive style and working memory are expected to be significant positive predictors of mathematical performance when the effects of the amount of math homework completed by students and their prior math knowledge are controlled.

\section{Method}

\section{Participants}

A total of $209 \mathrm{k} 9$ high school female students (aged 15-16 years old) from 8 classes from public schools of Esfehan province (Shahreza city), participated in the study. The data from 26 students, who failed to complete the tests, were dropped from the analyses, leaving 183 students in the final sample. For this purpose, stratified random sampling design was used. This study was conducted during regular school hours in intact classes in October and November of the 2011/2012 school year.

\section{Instruments}

The research instruments were:

Homework questionnaire.Mathematics homework completion was measured by one item dealing with amount of percentages of mathematics homework completed: "How many percentages of your mathematics homework do you complete really?" Response categories were $25 \%$ (coded -1), 50\% (coded 0) and 75\% (coded 1). This item is similar to the most widely used measure of students' quantity of homework in prior research (Cooper et al., 1999).

Digit span backwards test (DBT).For the measurement of the student's working memory capacity (WMC), DBT has been quoted as the normal test (Case 1974; Scardamalia 1977; Al-Naeme 1989, Niaz, 1988; Talbi 1990; Johnstone et al. 1993; Alamolhodaei, 2009; Raghubar et al., 2010). The sequence of numbers were presented by an expert and the students are asked to turn the numbers over in their mind then reproduce the sequence in the reverse order of presentation and write it down from left to right on their answer sheets. Students were tested by DBT two times within 2 months as a test and retest. WMC was originally has five plus or minus two storage unit. 
Group-Embedded Figures Test (GEFT). The GEFT (Group Embedded Figures Test) created by Oltman et al. (1971) translated to Greek was used to measure FD/I. The GEFT is a common test used in similar studies to measure field dependence/independence. The GEFT examines subjects' ability to identify a simple figure which is embedded in a more complex pattern. There are 8 simple and 20 complex figures, which make up the GEFT. The estimate of reliability of the GEFT is .82 (Witkin, Oltman, Raskin, \& Karp, 1971). Students' cognitive styles were determined according to a criterion used by (Scardamalia 1977; Case 1974; Case and Globerson 1974; Johnstone et al. 1993; Alamolhodaei 1996, Alamolhodaei 2002, 2009).

Prior mathematics knowledge. The students' mathematics score on the math test administered at the end of the previous academic year (year 2010-2011) was used as the index of students' prior math knowledge.

Mathematics exam.Math exam was an ordinary class exam that was consisted of 18 questions based on freshman high school math syllabi. This exam is designed with cooperation and monitoring students' teachers by the researchers during two weeks.

\section{Procedure}

In this study, the GEFT (Group Embedded Figures Test) created by Oltman et al. (1971) was used to measure FDI. The FDI score for each student was the total number of embedded figures that were correctly. Each correct answer was assigned one point. Within the next week, another test was administered to the subjects, to measure working memory capacity. The tests were conducted in the regular classroom during scheduled class time and directions were read aloud to students. Beside, students' prior math knowledge score were collected from their schools at the beginning of semester. In addition, at the end of 6th week, the homework questionnaire was administered to the participants to identify the amount of percentages of mathematics homework completed by them. Table 1 shows this distribution. Finally, with the assistance of the various teachers whose classes were used for the study, the sample members were administered a mathematics test in order to assess their math performance at the end of two months. 
Table1. The distribution of groups of the amount of math homework completed by students over the sample

\begin{tabular}{llll}
\hline Group & $25 \%$ & $50 \%$ & $75 \%$ \\
\hline Total & $\mathrm{n}=31$ & $\mathrm{n}=78$ & $\mathrm{n}=74$ \\
$\mathrm{n}=183$ & $16.9 \%$ & $42.6 \%$ & $40.4 \%$ \\
\hline
\end{tabular}

\section{Data analysis}

Data of the present study were analyzed by descriptive and inferential statistics. Table 2 presents the means (M), standard deviations (SD) and score ranges for all variables in the study. Hypotheses of the study were analyzed by standard multiple regressions with the Statistical package for the Social Sciences (SPSS).

Table2. Means, standard deviations and ranges of variables for total sample (183).

\begin{tabular}{llll}
\hline & Mean $(\mathrm{M})$ & SD & Score range \\
1.Mathematical performance & 13.13 & 4.86 & 18 \\
2.WMC & 3.80 & 1.07 & 4 \\
3.Prior math achievement & 16.66 & 3.33 & 10 \\
4.GEFT score & 7.00 & 3.6 & 16 \\
\hline
\end{tabular}

\section{Results}

Correlations among variables (see Table 3) for the total sample showed that working memory was positively and moderately correlated with cognitive style $(r=.40)$. Also, The Pearson's correlation between these psychological variables was significant at the 0.01 level. The significant correlation among the two variables are not surprising, given the correlation found in previous research using similar scales such as Alamalhodaie's (2009) study (working memory and cognitive style, $r=.50$ ). The correlations between mathematical performance (the dependent variable) with working memory and cognitive style generally conformed to the study hypotheses. That is, cognitive style had a strong positive correlation with mathematical performance $(\mathrm{r}=.58)$, also there was moderate positive correlation between working memory and mathematical performance $(\mathrm{r}=.43)$. 
Table3. Correlations among study variables

\begin{tabular}{|c|c|c|c|c|c|}
\hline & 1. & 2. & 3. & 4. & 5. \\
\hline 1.Mathematical performance & 1 & & & & \\
\hline 2.WMC & $0.43^{\mathrm{a}}$ & 1 & & & \\
\hline 3.Prior math knowledge & $0.78^{\mathrm{a}}$ & $0.35^{\mathrm{a}}$ & 1 & & \\
\hline 4.GEFT score & $0.58^{\mathrm{a}}$ & $0.40^{\mathrm{a}}$ & $0.47^{\mathrm{a}}$ & 1 & \\
\hline 5.Amount of math homework completed & $0.53^{\mathrm{a}}$ & $0.21^{\mathrm{b}}$ & $0.46^{\mathrm{a}}$ & $0.31^{\mathrm{a}}$ & 1 \\
\hline
\end{tabular}

To explore which variables were relatively most important in predicting math performance, standard regression analyses were performed by entering the variables that correlated with math performance (working memory capacity and cognitive style) and assessing their relative contribution to mathematical performance (see Table 4). Models 1 and 2 report the bivariate regressions or the effect of each psychological variable on mathematical performance. With all the variables standardized, these coefficients represent a measure of effect size. A one standard deviation increase in working memory capacity was associated with a 0.43 standard deviation increase in mathematical performance $(\mathrm{p}<0.001)$. A one standard deviation increase in cognitive style was associated with a 0.58 standard deviation increase in mathematical performance $(\mathrm{p}<0.001)$.

Models 3 and 4 included working memory variable as predictor but prior math knowledge and amount of math homework completed were used as covariates, respectively. When controlling for prior math knowledge, the size of the coefficient for working memory decrease to 0.17 ( $\mathrm{p}<0.001)$. However, this size fell to $0.32(\mathrm{p}<0.001)$ after the effect of amount of math homework completed was adjusted.

Models 5 and 6 included cognitive style with prior mathematics knowledge and the amount of math homework completed controls, respectively. In model 5, the size of the regression coefficient reduces to 0.26 when the influence of prior math knowledge was controlled. In model 6, this coefficient fell to 0.46 but remained significant at 0.01 level. Model 7 included all two psychological variables in the same regression but no covariates. In Model 7 cognitive style had a larger regression coefficient in contrast with working memory capacity $(0.49, \mathrm{p}<0.001)$. In model 8 and 9 , multiple regressions was conducted by entering working memory and cognitive style as predictors with prior math knowledge and the amount of math homework completed were used as covariates, respectively. After the adjustment for the 
Table 4. Standard regression models for students' mathematical performance

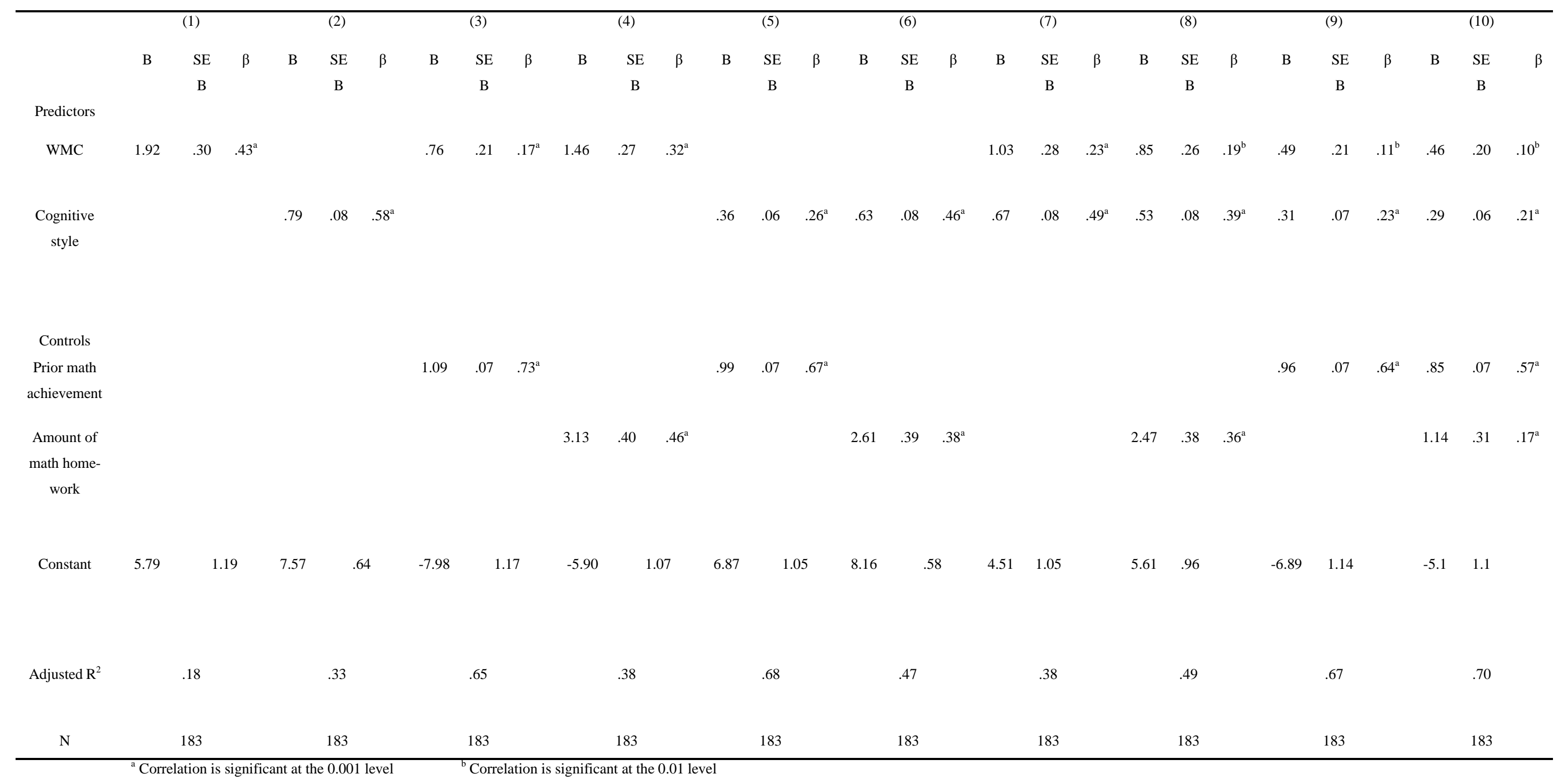


amount of math homework completed, results showed that the beta weight of cognitive style and working memory decrease to $0.39(\mathrm{p}<0.001)$ and $0.19(\mathrm{p}<0.01)$, respectively. But the both of these coefficients remained statistically significant. In addition, in model 9, when controlling for the effect of prior math knowledge, these coefficient for cognitive style and working memory diminish to $0.23(\mathrm{p}<0.001)$ and $0.11(\mathrm{p}<0.01)$, respectively.

Along with all two psychological variables, Model 10 included prior mathematics knowledge and the amount of math homework completed controls. The size of the coefficient for cognitive style fell to 0.21 but remained statistically significant at 0.001 level. Also, the size regression coefficient for working memory decrease to 0.10 but was still significant at 0.01level. Finally, standardized coefficients indicated that both predictors were positively correlated with mathematical performance and also, cognitive style was stronger predictor of math performance than working memory.

\section{Discussion and Conclusions}

Mathematics educators have long recognized the unique differences among individuals and the impact these differences can have on learning and performance. Concern for these differences led to research on the cognitive variables that individuals possess. The cognitive style, field dependence/independence, (Witkin, Moore, Goodenough, \& Cox, 1977) and working memory (Swanson, 1994; Fürst \& Hitch, 2000; Heathcote, 1994; Kyoung-Min \& SoYoung, 2002; Logie, Gilhooly, \& Wynn, 1994) have been recognized as having widespread implications for education. Therefore, the first purpose of this study was 1) to investigate whether cognitive styles and working memory capacity could predict mathematical performance and 2) to explore which variable was relatively most important in predicting math performance. So, we used data of 183 samples of K9 school girls and inferential statistical analysis using standard regression was carried out to identify variables that best predicted students' math performance.

Standard regression results revealed that both predictors were correlated with mathematical performance and consistently predicted math performance. Also, standardized coefficients indicated that cognitive style $(\beta=0.58$, model1) was the strongest predictor of mathematical performance. Also, working memory capacity ( $\beta=0.43$, model 2$)$ appeared to be moderator than cognitive style in the prediction of mathematical performance in $\mathrm{k} 9$ grade. Find- 
ings of this study support previous claims that student' cognitive style (Witkin and Goodenough 1981; Talbi 1990; Johnstone and Al-Naeme 1991, 1995; Alamolhodaei 1996; Sirvastava 1997; Ekbia and Alamolhodaei 2000; Alamolhodaei 2002; Alamolhodaei 2009) and working memory (e.g., Adams \& Hitch, 1998; Bull \& Scerif, 2001; Siegel \& Ryan, 1989; Hitch, 1978, Ekbia and Alamolhodaei 2000; Alamolhodaei 2002; Alamolhodaei 2009) could predict mathematical performance and also have important implications for the educational process.

Bandura (1997) attributes a very important role to prior knowledge and its effect on students' subsequent attainment. He also emphasizes the inclusion of prior knowledge in causal analyses. Therefore, we entered this factor as covariate in the models to identify main effects of predictors. Also, it seems that doing math homework may influence on relationship between working memory capacity and cognitive style with mathematical performance. So, the second objective of the study was to find whether cognitive styles and working memory capacity could predict mathematical performance when the impacts of students' prior math knowledge and the amount of math homework completed were controlled. After adjusting for the impacts of these factors on relationship between working memory and math performance, separately, finding of standard multiple regressions exhibited that working memory was still statistically significant predictor of math performance. In addition, as can be seen in model3 and 4 the beta weights of working memory reduced to $0.32(\mathrm{p}<0.001)$ and $0.17(\mathrm{p}=0.02)$, respectively. That is, students' prior math knowledge and the amount of math homework completed may moderate the influence of working memory on math performance.

As for the hierarchical nature of mathematical knowledge, it can be concluded that students who have high prior knowledge can decrease working memory overload in problemsolving situations and also during learning. In addition, doing math homework may help students to reinforce material and master a subject or skill and it seems that working memory loads may be reduced when students' skill proficiency increase. Therefore, having strong prior math knowledge and completing math homework may diminish the effect of working memory on students' mathematical performance. Also, the results of multiple regressions showed that cognitive style predicted students' math performance when prior math knowledge and the amount of math homework completed controls were included, separately. It indicated that the impact of cognitive style on mathematical performance was still significant and the students who gain high disembedding ability score received significantly better mathematical performance than those gain low score. As can be seen in model 4 and 5, the 
size of the regression coefficients reduced to 0.17 and 0.26 , respectively. It showed that regardless of type of students' cognitive style, having high prior math knowledge can help learners to solve math problems and understand math concepts.

Also, students can experience different methods of math problem solving, practice skills and develop their critical thinking skills when they effort to complete their math homework. So, doing homework and having high prior knowledge may diminish the negative effect of being field dependent on math performance. In model 7, study results discovered that cognitive style was stronger predictor of math performance than working memory, that is, students who maintain higher levels of disembedding ability score had the largest gains in mathematical performance in this sample. Finally, finding of present study exhibited that cognitive style and working memory were still significant predictors of students' math performance when the influence of both students' prior math knowledge and the amount of math homework completed were controlled. In addition, as can be seen in model10 the beta weights of cognitive style and working memory reduced to $0.21(\mathrm{p}<0.001)$ and $0.10(\mathrm{p}=0.02)$, respectively. That is, students' prior math knowledge and the amount of math homework completed may decrease the influence of individual factors (cognitive style and working memory) on math performance.

It seems to the researcher of this study that the effect of students' cognitive style and working memory on math performance may be decreased when learner complete their math homework frequently and have high prior math knowledge. It seems safe to conclude that low WMC or low disembedding ability (that is, field dependency) students who complete their math homework or enhance prior math knowledge could improve their math performance and compensate deficiency in their cognitive variables. Completing math homework may help students learn math skills, practice or review material that has already been presented in class (Becker \& Epstein, 1982) and relate new information to their prior knowledge. Thus, it seems that mathematics teachers should assign homework that strengthens the targeted skills and knowledge but in a way that is relevant and interesting to students' who all too often see homework as a costly venture in school (Coutts, 2004). Studies have suggested that students are more likely to complete homework successfully when assignments are matched to their preferred learning styles (Nuzum, 1998; Paulu, 1998). Thus, preparing math assignment homework that takes into account individual students' learning styles can have a positive influence on homework completion rates. In addition, according to the present study, it could be 
suggested that math teachers inform students of hierarchical structure of mathematics knowledge and the role of previous math knowledge in understanding new concepts.

\section{Limitations}

The present research has certain limitations. For instance, the study sampled students from a restricted age range (15-16 years old) and is focused on k9 graders. Moreover, all samples were drawn from 4 public high schools in one city of Iran and the present study was restricted to mathematics lesson. The findings of the present study are based upon female student samples. Consequently, further experiments are necessary perhaps under more specific conditions for finding more information, in particular for male students. Thus, it seems it's important that mathematics teachers are made aware of the role played by cognitive and affective factors as predictor variables in determining student success. This study results can be used for students' school guiding, giving mathematical homework to learners and it helps teachers to know their students better and to teach in a more effective way.

\section{References}

Adams, J. W., \& Hitch, G. J. (1998). Children's mental arithmetic and working memory. In C. Donlan (Ed.), The development of mathematical skills (pp. 153-173). East Sussex, UK: Psychology Press Ltd.

Alamolhodaei, H. (1996). A study in higher education calculus and students' learning styles. Ph.D. Thesis, University of Glasgow, Glasgow, UK.

Alamolhodaei, H. (2002). Students' cognitive style and mathematical problem solving. Journal of the Korea Society of Mathematical Education. Series D: Research in Mathematical Education, 6(1), 171-182.

Alamolhodaei, H. (2009). A Working Memory Model Applied to Mathematical word Problem Solving. Asia Pac. Educ. Rev, 10(1), 183-192.

Alamolhodaei, H., \& Ghazvini, H. (2003). Student's working memory and mathematical problem solving in higher education. Unpublished manuscript, Ferdowsi University of Mashhad, Iran.

Al-Naeme, F. F. A. (1989). A study of some psychological factors affecting performance in chemistry and tertiary levels. M.Sc. Thesis, University of Glasgow, Glasgow, UK.

Altun, A., \& Cakan, M. (2006). Undergraduate Students' Academic Achievement, Field Dependent/Independent Cognitive Styles and Attitude toward Computers. Educational Technology \& Society, 9 (1), 289-297. 
Aminzadeh, A. \& Sarmad, Z. (2009). Homework and academic achievement: the modifynig role of mother's level of education and student's gender. Journal of Iranian Psychologists, 6(21), 55-60.

Ashcraft, M. H. (1995). Cognitive psychology and simple arithmetic: A review and summary of new directions. Mathematical Cognition, 1, 3-34.

Ashcraft, M. H., \& Kirk, E. P. (2001). The relationship among working memory, math anxiety, and performance. Journal of Experimental Psychology: General, 130, 224-237.

Atkinson, R.C. \& Shiffrin, R.M. (1968). Human memory: A proposed system and its control processes. In K.W. Spence (Ed.), The psychology of learning and motivation: Advances in research and theory, Vol. 2 (pp. 89-195). New York: Academic Press.

Ausubel, D. P. (1963). The psychology of meaningful verbal learning. New York: Grune \& Stratton.

Ausubel, D. P. (1968). Educational psychology: A cognitive view. New York: Holt, Rinehart and Winston.

Ausubel, D. P., Novak, J. D., \& Hanesian, H. (1978). Educational psychology: A cognitive view ( $2^{\text {nd }}$ ed.). New York: Holt, Rinehart and Winston Beasley, R., \& Waugh, M. L. (1995). Cognitive mapping architectures and hypermedia disorientation: An empirical study. Journal of Educational Multimedia and Hypermedia, 4(2/3), 239-255.

Baddeley , A. D ., Emslie, H ., Kolodny, J., \& Duncan , J . (1998). Random generation and the executive control of memory. Quarterly Journal of Experimental Psychology, 51A, 819-852.

Baddeley, A.D . (1996). Exploring the central executive. Quarterly Journal of Experimental Psychology, 49 A, 5-28.

Baddeley, A. (2000). The episodic buffer: A new componet of working memory? Trends in Cognitive Sciences, 4, 417-423.

Baddeley, A. D., \& Hitch, G. J. (1974). Working memory. In G. H. Bower (Ed.), The psychology of learning and motivation (pp. 47-90). New York: Academic Press.

Baddeley, A. D., \& Logie, R. H. (1999). Working memory: The multiple-component model. In A. Miyake \& P. Shah (Eds.), Models of working memory: Mechanisms of active maintenance and executive control (pp. 28-61). Cambridge, UK: Cambridge University Press.

Bahar, M. \& Hansell, M. (2000). The relationship between some psychological factors and their effects on the performance of grid questions and word association tests. Educa- 
The role of mathematical homework and prior knowledge on the relationship between students' mathematical performance, cognitive style and working memory capacity

tional Psychology: An International Journal of Experimental Educational Psychology, 20, 349-363.

Bandura, A. (1997). Self-efficacy: The exercise of control. New York: W.H. Freeman \& Company.

Becker, H. J., \& Epstein, J. L. (1982). Parent involvement: A survey of teacher practices. Elementary School Journal, 83, 85-102.

Brainerd, C. J. (1983). Young children's mental arithmetic errors: A working memory analysis. Child Development, 54, 812-830.

Bull, R., \& Scerif, G. (2001). Executive functioning as a predictor of children's mathematics ability: Inhibition, switching, and working memory. Developmental Neuropsychology, 19, 273-293.

Cakan, M. (2000). Interaction between cognitive styles and assessment approaches. Unpublished doctoral dissertation, Louisiana State University, USA. Baton Rouge.

Cary, M., \& Carlson, R. A. (2001). Distributing working memory resources during problems solving. Journal of Experimental Psychology: Learning, Memory, \& Cognition, 27, 836-848.

Case, R. (1974). Structures and strictures, some functional limitations on the course of cognitive growth. Cognitive Psychology, 6, 544-574.

Case, R., \& Globerson, T. (1974). Field-independence and central computing space. Child Development, 45, 772-778.

Cooper, H. (1989). Synthesis of research on homework. Educational Leadership, 3, 85-91.

Cooper, H. (2007). The Battle Over Homework: Common Ground for Administrators, Teachers, and Parents. Thousand Oaks, CA: Corwin Press.

Cooper, H., Robinson, J.C., \& Patall, E.A. (2006). Does Homework Improve Academic Achievement? A Synthesis of Research, 1987-2003. Review of Educational Research, 76(1), 1-62.

Cooper, H., Valentine, J. C., Nye, B., \& Lindsay, J. J. (1999). Relations between five after school activities. Journal of Educational Psychology, 91 (2), 369-378.

Coutts, P. M. (2004). Meanings of homework and implications for practice. Theory into practice, $43,182-188$.

Daneman, M., \& Carpenter, P. A. (1980). Individual differences in working memory and reading. Journal of Verbal Learning and Verbal Behavior, 19(4), 450-466.

DeStefano, D., \& LeFevre, J. (2004). The role of working memory in mental arithmetic. European Journal of Cognitive Psychology, 16, 353-386. 
Ekbia, A., \& Alamolhodaei, H. (2000). A study of the effectiveness of working memory and cognitive style on mathematical performance of (13-year-old) school boys. M.A Thesis, Teacher Training University of Tehran, Iran.

Fürst, A. J., \& Hitch, G. J. (2000). Separate roles for executive and phonological components of working memory in mental arithmetic. Memory \& Cognition, 28, 774-782.

Gathercole, S. E., Pickering, S. J., Ambridge, B., \& Wearing, H. (2004). The structure of working memory from 4 to 15 years of age. Developmental Psychology, 40, 177-190.

Geary, D. C., Brown, S. C., \& Samaranayake, V. A. (1991). Cognitive addition: A short longitudinal study of strategy choice and speed-of-processing difference in normal and mathematically disabled children. Developmental Psychology, 27, 787-797.

Grigorenko, E.L., \& Sternberg, R.J. (1995). Thinking styles. In D.H. Saklofske \& M. Zeidner (Eds.), International handbook of personality and intelligence. (pp. 205 -29) New York, NY: Plenum.

Hallam, S. (2004). Homework: The evidence (bedford Way Papers). London: Institute of Education, University of London.

Heathcote, D. (1994). The role of visual-spatial working memory in the mental addition of multi-digit addends. Cahiers de Psychologie Cognitive, 13, 207-245.

Henderson, M. (1996). Helping your student get the most out of homework. Washington, DC: National Education Association.

Hitch, G. (1978). The role of short-term working memory in mental arithmetic. Cognitive Psychology, 10, 302-323.

Johnstone, A. H., \& Al-Naeme, F. F. (1991). Room for scientific thought. International Journal of Science Education, 13(2), 187-192.

Johnstone, A. H., \& Al-Naeme, F. F. (1995). Filling a curriculum gap in chemistry. International Journal of Science Education, 17(2), 219-232.

Johnstone, A. H., Hogg, W. R., \& Ziane, M. (1993). A working memory model applied to physical problem solving. International Journal of Science Education, 15(6), 663-672.

Kang, S., Scharmann, L. C., Noh, T. \& Koh, H. (2005). The influence of students' cognitive and motivational variables in respect of cognitive conflict and conceptual change. International Journal of Science Education, 27(9), 1037-1058.

Klein, J. S., \& Bisanz, J. (2000). Preschoolers doing arithmetic: The concepts are willing but the working memory is weak. Canadian Journal of Experimental Psychology, 54, $105-115$.

Kyoung-Min, L. \& So-Young, K. (2002). Arithmetic operation and working memory: Differ 
The role of mathematical homework and prior knowledge on the relationship between students' mathematical performance, cognitive style and working memory capacity

erential suppression in dual tasks. Cognition, 83, 63-68.

Lee, J. F. \& Pruitt, K. W. (1979). Homework assignments: Class games or teaching tools? Clearing House, 53, 31-35.

Liu, M., \& Reed, W. M. (1994). The relationship between the learning strategies and learning styles in a hypermedia environment. Computers in Human Behavior, 10(4), 419-434.

Logie, R. H., Gilhooly, K. J., \& Wynn, V. (1994). Counting on working memory in arithmetic problem solving. Memory \& Cognition, 22, 395-410.

Mabbot, D. J., \& Bisanz, J. (2008). Computational skills, working memory, and conceptual knowledge in older children with mathematics learning disabilities. Journal of Learning Disabilities, 41, 15-28.

Mayer, R. E. (2001). Multimedia learning. New York: Cambridge University Press.

Mousavi, S. Y., Low, R., \& Sweller, J. (1995). Reducing cognitive load by mixing auditory and visual presentation modes. Journal of Educational Psychology, 87(2), 319-334.

Mulhenbruck, L., Cooper, H., Nye, B. \& Lindsay, J. J . (1999). Homework and achievement: Explaining the different strengths of relation at the elementary and secondary school levels. Social Psychology of Education, 3, 295-317.

Murphy, H. J., Casey, B., Day, D. A., \& Young, J. D. (1997). Scores on the Group Embedded Figures Test by undergraduates in information management. Perceptual and Motor Skills, 84, 1135-1138.

Nasser, R., \& Carifio, J. (1993). The effects of cognitive style and Piagetian logical reasoning on solving a propositional relation algebra word problem. Paper presented at the North England Educational Research Organization. Portsmouth, NH (ERIC Document Reproduction Service).

Niaz, M. (1988). The information-processing demand of chemistry problems and its relation to on academic achievement. Contemp. Educ. Psychol, 16, 28- 44.

Nuzum, M. (1998). Creating Homework Success - Improving Quality of Homework for Students. Instructor, 108 (3), 86-91.

Pajares, F. (1996). Self-efficacy beliefs and mathematical problem-solving of gifted students. Contemporary Educational Psychology, 21, 325-344.

Pascual-Leone, J. (1989). An organismic process model of Witkin's field dependence- independence. In T. Globerson \& T. Zelniker (Eds.), Cognitive style and cognitive development (pp. 36-70). Norwood, NJ: Ablex. 
Passolunghi, M. C., \& Siegel, L. S. (2001). Short-term memory, working memory, and inhibitory control in children with difficulties in arithmetic problem solving. Journal of Experimental Child Psychology, 80, $44-57$.

Paulu, N. (1998). Helping Your Students With Homework: A Guide for Teachers. Washington, DC: Office of Educational Research and Improvement, U.S. Department of Education. Retrieved from http://www.ed.gov/PDFDocs/hyc.pdf.

Quiroga, M. A., \& González, A. (1988). Guía documental y análisis bibliométrico sobre los estilos cognitivos y los controles cognitivos. Investigaciones Psicológicas, 5, 177-235.

Raghubar, K.P., Barnes, M.A. \& Hecht, S.A. (2010). Working memory and mathematics: A review of developmental, individual difference, and cognitive approaches. Learning and Individual Differences, 20, 110-122.

Rosen, V. M., \& Engle, R. W. (1997). The role of working memory capacity in retrieval. Journal of Experimental Psychology. General, 126, 211-227.

Scardamalia, M. (1977). Information processing capacity and the problem of horizontal decalage: A demonstration using combinatorial reasoning tasks. Child Development, $48(1), 28-37$.

Seitz , K., \& Schumann-Hengsteler, R. (2000). Mental multiplication and working memory. European Journal of Cognitive Psychology, 12, 552-570.

Shellard, E.G., \& Turner, J.R. (2004). Homework: Research and Best Practice. ERS Focus On. Educational Research Service, Arlington, VA.

Siegel, L. S., \& Ryan, E. B. (1989). The development of working memory in normally achieving and subtypes of learning disabled children. Child Development, 60, 973-980.

Swanson, H. L. (2004). Working memory and phonological processing as predictors of children's mathematical problem solving at different ages. Memory and Cognition, 32, $648-661$.

Swanson, H. L., \& Beebe-Frankenberger, M. (2004). The relationship between working memory and mathematical problem solving in children at risk and not at risk for serious math difficulties. Journal of Educational Psychology, 96, 471-491.

Swanson, L. H. (1994). Short-term memory and working memory: Do both contribute to our understanding of academic achievement in children and adults with learning disabilities?. Journal of Learning Disabilities, 27, 34-50.

Talbi, M. T. (1990): An information processing approach to the investigation of mathematical problem solving at secondary and university levels. Ph.D. Thesis, University of Glasgow, Glasgow,UK. 
The role of mathematical homework and prior knowledge on the relationship between students' mathematical performance, cognitive style and working memory capacity

Tinajero, C., \& Páramo, M.F. (1998). Field dependence -independence cognitive style and academic achievement: A review of research and theory. European Journal of Psychology of Education, 13(2), 227-251.

Tsaparlis, G. (2005). Non-algorithmic quantitative problem solving in university physical chemistry: A correlation study of the role of selective cognitive factors. Research in Science and Technological Education, 23, 125-148.

Wechsler, D. (1955). Wechsler adult intelligence scale manual. New York: Psychological Corporation.

Witkin, H. A., \& Goodenough, D. R. (1981). Cognitive style: Essence and origins. New York: International Universities Press.

Witkin, H. A., Oltman, P., Raskin, E., \& Karp, S. (1971). A manual for the embedded figures test. Palo Alto, CA: Consulting Psychologists Press.

Witkin, H.A., Dyk, R.B., Paterson, H.F., Goodenough, D.R. \& Karp, S.A. (1974). Psychological differentiation. New York: Wiley.

Witkin, H.A., Moore, C.A., Goodenough, D.R., \& Cox, P.W. (1977). Field dependent and field independent cognitive styles and their educational implications. Review of Educational Research, 47, 1-65. 
Shima Mousavi et al.

[This page intentionally left blank] 